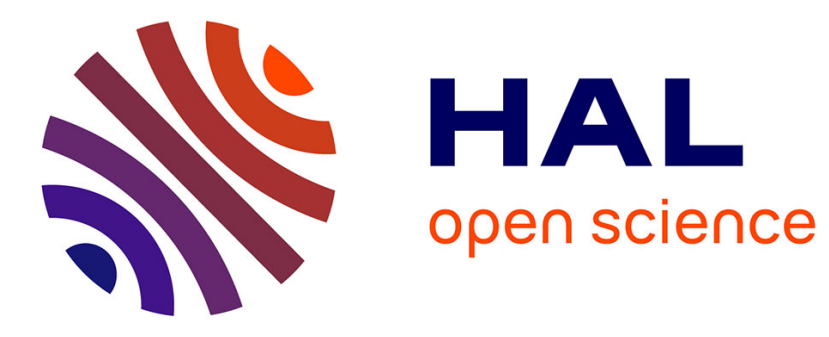

\title{
Agricultural Fire or Arson?
}

Antonin Plarier

\section{To cite this version:}

Antonin Plarier. Agricultural Fire or Arson?: Rural Denizens, Forest Administration, and the Colonial Situation in Algeria (1850-1900) . Historical Reflections/Réflexions Historiques, 2020, 46 (2), pp.9-24. 10.3167/hrrh.2020.460202 . hal-03448978

\section{HAL Id: hal-03448978 https://hal.science/hal-03448978}

Submitted on 25 Nov 2021

HAL is a multi-disciplinary open access archive for the deposit and dissemination of scientific research documents, whether they are published or not. The documents may come from teaching and research institutions in France or abroad, or from public or private research centers.
L'archive ouverte pluridisciplinaire HAL, est destinée au dépôt et à la diffusion de documents scientifiques de niveau recherche, publiés ou non, émanant des établissements d'enseignement et de recherche français ou étrangers, des laboratoires publics ou privés. 


\section{Agricultural Fire or Arson?}

Rural Denizens, Forest Administration, and the Colonial Situation in Algeria (1850-1900)

Antonin Plarier

Abstract: This article focuses on fire management practices in Algeria during the colonial period. Focusing on environmental usages of fires in Algerian rural society, this article shows that these practices were submitted to varied and opposite interpretations resulting in significant and durable conflicts. These conflicts exploded under the French colonial forestry administration, which forcefully imposed new legislation to criminalize existing agricultural practices, including fires. Despite this ban, these practices continued. The administration interpreted this persistence as rebellion and responded with severe sanctions. This only aggravated the situation, resulting in a real war of attrition. On the one hand, this situation does not diverge from the rural violence typical of the nineteenth century. On the other, the responses of the administration in colonial Algeria represent specific digressions compared to the policies carried out in metropolitan areas.

Keywords: agricultural fires, Algeria, arsons, collective punishment, colonial administration, cork oak forests, forestry

On 19 October 1865, a criminal court condemned to death Ahmed ben Si Dehmou, a 30-year-old Algerian peasant. A jury composed entirely of French citizens and settlers delivered the guilty verdict. The so-called arson had happened two months before, on 25 August, "a day, we must believe, collectively chosen for these kind of attacks since at the very same time, in all 3 
departments of Algeria, fires threatened populations" asserted the president of the Assize Court. ${ }^{1}$ The accused was mentioned as "coming from the Hadjoute tribe," a population that led a substantial insurrection in 1839 and was still considered a "rebellious tribe" by colonial authorities. ${ }^{2}$ This social categorization surely did not help Dehmou during his trial. The association of a fire perpetrated by an individual with rebellious politics gave the proceedings a political meaning. Widely read metropolitan newspapers, including Le Temps, Le Petit Parisien, and La Presse extensively reported on the trial. ${ }^{3}$ Thus it became a forceful defense of colonial settlement in the face of "indigenous threats." However, one problem persisted: Ahmed ben Si Dehmou was not a declared opponent of colonization. In his defense, he argued that a disagreement with his brother led him to set fire to the latter's plot of land, not a hostile act against colonial authority, and the judge seemed to give respectable credit to the accused's story.

Nonetheless, the act embodies part of a broader context characterized by multiple tensions around colonial domination. At the very least, colonists as well as civil servants perceived their control as fragile. Ahmed ben Si Dehmou's action took place during the summer of 1865, a period when large fires particularly worried colonial authorities and public opinion. ${ }^{5}$ The imperial prosecutor explicitly linked the fire in question with summer arson across the region and the perceived political motivations of the accused, deplored as representing the hostility of all Algerians: "This is what these Arabs are today, surrounded by so much kindness. What they could not do against the power of our weapons, they try to achieve today by attacking our properties. Their audacity knows no borders; terror reigns in our countryside and public safety would be forever compromised if a terrible example does not come to stop the criminal enterprises of these men who have never known any other laws than the one of force and fear." ${ }^{\prime 6}$ 
The eventual execution of Ahmed ben Si Dehmou illustrates the extreme tension in Algeria concerning fires and their corollary: colonial security. Criminal or administrative sanction constitutes for the historian a privileged gateway to understanding Algerian society and its rural and colonial ambitions. ${ }^{7}$ The action of Ahmed ben Si Dehmou reveals a conflictual configuration open to diverse interpretations. The significance of this type of act is necessarily varied, and this plurality reflects a number of historical actors pursuing distinct interests. By bringing to light discursive rivalries, the issue of punishment reveals a snapshot of a society and its conflicts over primary resources. How did the agricultural uses of fire collide with the approaches of rational forestry imposed in nineteenth-century Algeria? Forest fires were indeed accompanied by legitimizing or disqualifying speeches that revealed what was at stake. The will of the forestry administration to eradicate this agricultural practice resulted in severe repression, much as observed in metropolitan France and in other parts of the Empire. Nevertheless, the colonial level of punishment meted out in the colonial Algerian setting differed substantially from the metropolitan situation.

\section{Forest fires: the birth of usage conflicts}

The practice of agricultural fires responded first to the need to regenerate land with the ashes of stubble and plants, which fertilized newly cleared shrub land. As Augustin Berque, former director of indigenous affairs and sociologist of rural life, noted in 1934: "In Algeria, forest burning will always depend on pastoral needs. Colonization resulted in the seizure of indigenous arable land. Herds withered due to a lack of pasture. A good fire, and in the autumn sap produces a whole range of herbs." ${ }^{\prime 8}$ Fire was used to fertilize pastures for cattle but also cultivated land. In late summer, it provided a good fertilizer for planting seeds in early fall after clearing the soil of brambles and 
weeds that obstructed the growth of cereal crops. ${ }^{9}$ The phenomenon was not specific to Algeria. During the same period, these types of agricultural usage were quite common in the south of France and elicited precisely the same public debates under the Second Empire. ${ }^{10}$ Furthermore, in his study on the protection of Indochina's forests, Frédéric Thomas reported similar practices. Citing an 1860 statement by Clovis Thorel, member of the Permanent Commission on Indochina Forests:

They [the native peasants] cleared a site of two or three hectares with iron and fire, set up huts there, buffalo parks, and then cut around the village, improvising the biggest dâu, the Fri-Fri, and a few other rarer essences. But far from respecting the area they have just exploited and letting the forest build up, every year they cut down small or large trees that are easy to remove, set them on fire, and destroy them in this way. This is how they obtain a layer of ashes, which, mixed with humus, allow the rice to be sown without removing the roots and without any plowing. ${ }^{11}$

Thorel's observations echo Steven Pyne's theorization concerning the use of fire in rural societies before the intervention of rational forestry: "agriculturalists burned because they had to. Except for a handful of places, extensive farming and herding were impossible without burning." 12 This agricultural practice did not reflect any malevolence toward authority, yet it was precisely through this interpretive framework that the Indochinese, Var, and Algerian peasants were judged by the administration. As soon as the practice competed with the exploitation of precious forest resources by French concerns, it became stigmatized. In the vicinity of Saigon, easily accessible forests provided the young colony with heating fuel as well as valuable timber, quickly exploited and sold in mainland France. Significantly, one of the first decisions of Admiral de la Grandière, supreme 
commander of Indochina during the 1860s, aimed to challenge "the Indochinese monopoly" and to transfer it to the colonists by granting cutting permits to Europeans.

In her article on the vulnerability of the Provençal forest, Martine Chalvet demonstrates how conflicts over the use of forest space gave rise to an alarmist discourse on forest fires in the south of France: "Until the years 1850-1860, the exploitation of the woods of the Maures and the Esterel [Var Forests] remained traditional: temporary crops, grazing, charcoal manufacture, the use of firewood. However, in the second half of the nineteenth century, a new profitability from the exploitation of pines and cork oaks developed. The villages of Cogolin, Pierre-feu, Collobrières, La Garde-Freinet focused on these very profitable activities. In this new socioeconomic context, the perceptions of fires were radically transformed, the vulnerability of the massifs of the Maures and Esterel clearly affirmed in face of the fire risk."13

From this point of view, the development in Algeria of a discourse concerning "incendiary Arabs" borrows largely from a topos already built in mainland France. This speech nevertheless mirrors a development in Algeria, in which forests played a key role in terms of colonial development. In a narrative representative of the forestry expectations expressed by the colonial administration, Captain Léo Lamarque, an officer during the conquest, explained: "These forests, as inviolably preserved as the sacred woods of the ancients will one day cast their shade over all Algeria. They will maintain freshness through an abundance of sources; they will then offer the farmer a liquid, precious fertilizer, going itself to the fields, costing nothing, and all the more powerful as the sun is itself warmer. To the industrialist, the coal necessary for metallurgical work, and the essential engines; to the settlers, the timber required for the construction of their buildings; and finally, for the navy, supplies for its yards." 14 
Forests were considered a nodal point of colonization allowing a flourishing economy to be built. However, two elements disrupted this glorious and civilizing scheme: cattle and fire. The first is beyond the scope of this article, but the second proved equally problematic: that fires concerned colonial administrations and actors would be an understatement.

The fires of 1865 were the first to generate a major campaign against the destruction of Algerian forests. Chronologically, this campaign was contemporary with the beginning of cork oak forest exploitation, which was directly affected by the fires. ${ }^{15}$ Forests constituted one of the jewels of the Algerian colony. At the beginning of the 1860s, they were transformed into immense concessions attributed either to the wealthy or to elite personalities of the empire. By imperial decrees enacted between 1862 and 1863, 160,000 hectares of cork oak forests were conceded for 90 years to around 30 beneficiaries, with average concessions of more than 5,300 hectares per holding. ${ }^{16}$ These cork oak forests were immensely valuable and became the subject of considerable attention.

Customary rights in these spaces were then turned upside down. The local populations quickly lost the possibility of cultivating plots or grazing their cattle—activities that required slash and burn practices. The process of dispossession unfolded on several fronts, severely affecting the peasantry. On one hand, the state legally monopolized forest lands through the law of 16 June 1851. ${ }^{17}$ This law considered forests uncultivated lands, and as such, it classified them as state property. On the other hand, the exploitation of these forest resources also reflected a restriction, often brutal, of the customary rights that pre-existed over these spaces. Land dispossession and the lapse of customary rights combined to seriously impact forest populations. To be sure, such a confrontation of practices was not a specifically Algerian or even colonial phenomenon. ${ }^{18}$ Yet it nevertheless occurred at a particularly volatile moment. Indeed, from 1860 to 1870 , officials 
allocated cork oak concessions, and the repression of the uprising of 1871 also contributed to deeply transform the Algerian land situation. This insurrection spread over a third of the country, frightening colonial populations and authorities. ${ }^{19}$ In the aftermath, the seizure of land seriously affected and significantly impoverished the rural population.

Indeed, the individual and collective seizures of land following this insurrection covered $2,639,000$ hectares - the equivalent of five French departments. ${ }^{20}$ These parcels were not necessarily all confiscated insofar as the douars (the French colonial term for village) were able to buy back certain lots uninteresting to settlers, along with those not used to resettle displaced Algerian populations. According to the gouvernement général in 1878, seven communities saw their entire territory ceded to the colonial state $(309,614$ hectares $)$, in addition to 301,516 hectares of cultivated land or rangelands belonging to multiple communities also attached to state property. ${ }^{21}$ The trauma of the insurgency's repression was considerable. Poet Mohand Moussa powerfully captured this feeling: "They have burdened the poor with debts__Stolen their land_/ Taken their fields to the doors of their houses." 22

Land seizures formed only one part of the repressive apparatus of dispossession after the insurrection. The authorities "had stolen the land" but they were also accused of having "burdened the poor with debts. ${ }^{23}$ War reparations were effectively imposed of up to $36,582,000$ francs, to provide the necessary resources for the installation of settlers at a lower cost. ${ }^{24}$ Dispossession further contributed to an increase in the importance of livestock breeding in the rural economy at a time when the Algerian populations were constricted to small areas, making the fertilization of the remaining land through agricultural fires even more necessary. ${ }^{25}$ Thus a conflict that began in the 1860 s-1870s with an increased colonial offensive became all the more explosive. 
The fabric of the incendiary conflict in the nineteenth century.

In this context, legislators soundly attacked preexisting agricultural methods, echoing trends observed a few years earlier in mainland France. In 1870, the first law relating to forest fires applied to the Var forests in order to protect the exploitation of its cork oaks, rare in mainland France. Agricultural fires were then criminalized, with the peasants of Brignoles singled out by the Inspector of the Forestry Administration as the authors of "barbaric and customary" practices. ${ }^{26}$ Clearly such terminology was not confined to critiques of the practices of rural Algerians. Adopted on 6 July 1870, a law against fires in the wooded regions of the Maures and Esterel provided for the prohibition of fires during the summer periods, including both public domains and privatelyowned forests. Responsibility for the application of this provision lay with the prefect, with forest owners obliged to create and maintain ditches to stop the progression of a fire. Finally, the state undertook to participate in the construction of a forest communication network intended to facilitate the monitoring of wooded massifs. The similarities between provisions of this law and the one adopted four years later for Algeria are striking. Martine Chalvet underlines the existing connections between the cork oak concession holders in Algeria and Charles de Ribbe, Aix lawyer from the noblesse de robe, prolific essayist, and inspirer of the law of 6 July $1870 .{ }^{27}$ An explanatory memorandum to the law adopted for Algeria on 17 July 1874 pays tribute to this first legislative draft. $^{28}$

On July 6,1870 , a law relating to the measures to be taken against forest fires in the wooded region of Maures and Esterel (Var) was made enforceable. The reports of the Commissions appointed to the two chambers pointed out to the representatives of the nation the exceptional situation of this region whose forests, covering an area 
of 111,331 hectares, had been ravaged for twenty years by annual fires which had already destroyed almost 25,000 hectares and caused a loss of almost five million. Remedying these disasters and urgently taking exceptional preservation measures was, according to reports, a measure of public safety. There is not one of the considerations of fact and rights invoked in support of this law which does not apply with much more force and urgency to the situation of the forests of Algeria. ${ }^{29}$

Informed by the experience of the Var, several individuals decided to set up a structured association intended to influence colonial policy in forestry matters. In 1881, a league for the reforestation of Algeria was created and included many dignitaries of the colony: parliamentarians, senior civil servants, and large landowners but also modest settlers, civil servants or teachers, such as Algiers professor of medicine and essayist Paulin Trolard. ${ }^{30}$ The date of the foundation of their league was not accidental. At the end of this summer, fires covered gigantic areas at record levels unseen since the first measurements of the phenomenon two decades earlier. Hence the league organized throughout the colony and administration, its goals to educate political decision-makers through the construction of public opinion. In the first bulletin, Doctor Trolard appealed to Algerians: "Any deforested country is a country condemned to death. It is no longer a truth to demonstrate; science today has established it on irrefutable evidence. However, Algeria is a deforested country. The little forest that the teeth of his flocks have spared, the incendiary Arab threatens to remove from us in a few hours." 31

The discourse on the centrality of forests in the colonial economy was accompanied by a very clear concern that forests would be in the throes of decline and threatened by the fires supposedly perpetrated by the essentialist figure of the "incendiary Arab." 32 Analyzed by Diana 
K. Davis in her work Resurrecting the Granary of Rome, Environmental History and French Colonial Expansion, the discourse of decline is omnipresent in forestry publications and colonial literature. ${ }^{33}$ For example, Guy de Maupassant witnessed the 1881 fires and in his novel Au Soleil he repeats this topos without any nuance. In his story, the writer highlights the guilt of the "Kabyles," quoting La Dépêche de Djidjelli that "it is therefore evident that the fire has been set by the indigenous populations, and in execution of a given watchword." 34 The fires provided the occasion for virulent campaigns waged by the forest lobby in order to obtain the implementation of repressive legislation vis-à-vis Algerians and, eventually, reparations for fire devastation.

The fires of 1865 and 1871 indeed gave rise to compensation for forest concessionaires, their plots transformed into private properties under advantageous conditions. ${ }^{35}$ By 1881 , the fires set in motion a reforestation league, and a campaign in favor of a law relating to the management and the repurchase of the customary rights in the forests of Algeria. ${ }^{36}$ This law was conceived as an additional weapon in the war of attrition waged against Algerian peasant practices. Moreover, an 1885 law dangled the possibility for private and state forest owners to eradicate customary rights, highlighting pasturing, as they were not "an absolute necessity for the inhabitants" (art.1). It also made possible the removal of agricultural enclaves by way of expropriation for public utility in the national forests (art. 2). In addition, the ban on grazing in burnt forests was renewed. Nevertheless, the owners of cork oaks forests took over the State Council in order to be exempted from the latter interdiction. They advocated for an application restricted to forest users rather than owners and obtained satisfaction. ${ }^{37}$ This decision exclusively benefited Europeans, who could rent woodlands for pasture regardless of whether fires occurred. After all, the profitable exploitation of the forest remained the primary objective. 
For despite the league's environmentalist discourse, their intentions were far from benevolent. The objective of the law was clearly explained by Eugène Étienne, deputy of Oran, businessman, pillar of the "colonial party" and commentator on the law: "Without withdrawal of the rights of use and abolition of the (cultivated) enclaves, there will be no industrial exploitation of the forests. ${ }^{38}$ Étienne's assertion produced a discourse legitimizing repressive practices, and when coupled with the implementation of repressive legislation set the stage for a war of attrition against agricultural fires.

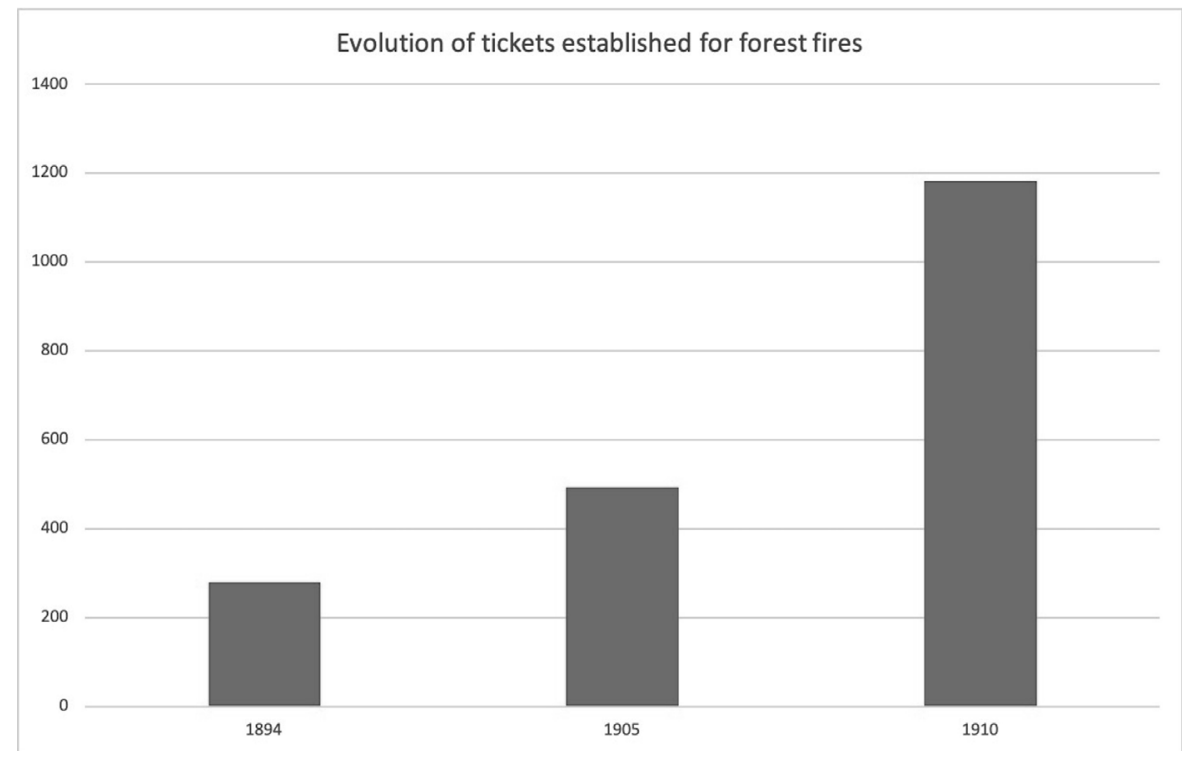

Figure 1. Source: Gouvernement général de l'Algérie, Exposé de la situation de l'Algérie (Algiers: Imprimerie Juillet Saint-Lager, 1895, 1906, 1912)

The number of tickets rose from 278 to 1,183 between 1894 and 1910, a seemingly low number compared to the forest population, which probably numbered more than a million people at the turn of the century. ${ }^{39}$ However, the increase is significant and reflects the rising concern of the forestry administration. In addition, fines for grazing or cultivation in burnt forests must be 
added to this number, activities that ultimately constituted the reason for forest fires. Thus, the actual number of tickets related to farming practice increases significantly:

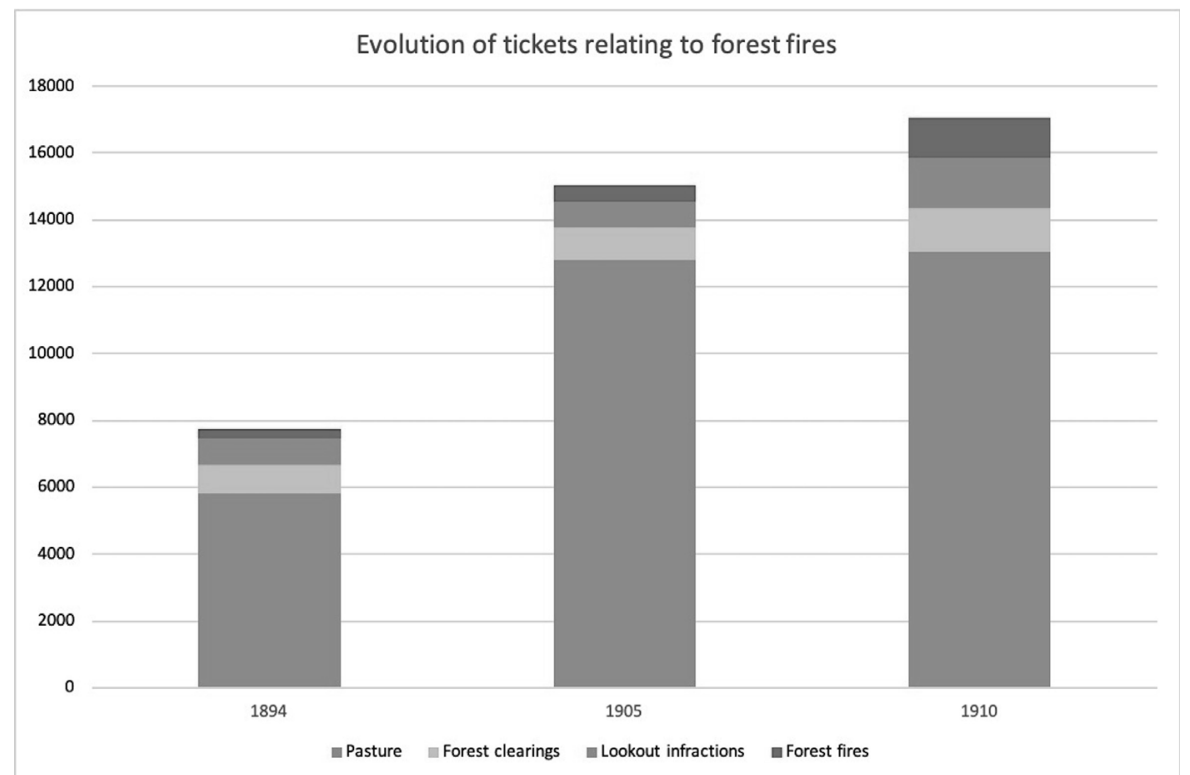

Figure 2.

Of course, grazing crimes were not necessarily linked to forest fires and occurred in forests that had not been burned. The extant sources do not distinguish between different infractions. By contrast, forest clearings were generally made by fires. The aggregate of these verbal offenses is nevertheless significant, and it is reasonable to believe that a sizeable portion occurred following a fire (grazing) or by means of a fire (clearing), while the frequency and extent of local forest fires can denote a significant increase in fires for grazing.

By 1910, noting the proliferation of grazing in a burnt forest in the Bouïra region, located 100 kilometers southeast of Algiers, forest inspectors demanded increased surveillance. On 31 October, the forest of Ain Hazem was the subject of an impromptu visit of the forest ranger in residence at Boukanafou. In one day, he issued nine tickets for illegal pasturing in a burnt forest. ${ }^{40}$ 
Obtained in a single day of surveillance, this figure illustrates the quotidian nature of the crime. The unexpected visit of the forest ranger, caused by the complaints of his superiors following reports of violations, also testifies to the looseness of the forest network. The forester invoked the large size of his triage (the lowest unity in forestry administration) to justify his previous alleged inaction. Naturally those fined disputed these tickets. In 1912, two years after the alleged infractions a petition from the rural inhabitants of Aï Hazem contested the legitimacy of the sanctions, targeting acts that took place in "forests belonging to them for an eternity even long before the conquest of Algeria under titles and plans etc." ${ }^{\prime 1}$ Thus were customary laws and historical precedents mobilized against the new forestry administration, a trend only heightened by the frequency of law enforcement. In 1899, 61 percent of crimes reported by forest rangers were grazing crimes, a relatively stable proportion over the entire period. Out of a total of 18,545 crimes representing fines totaling 325,000 francs, 250,000 francs were paid in kind. ${ }^{42}$ The proportion could increase in a given locale due to specific sanctions relating to pastures in burnt forests. In Miliana, violent fire investigations in 1903 represented 75 percent of the crimes committed in $1904 .{ }^{43}$

The forestry law adopted for Algeria in 1903 further sought to reduce these practices through a policy extending the scope of the crime, lengthening the grazing ban in burnt forests from six to seven years. However, despite the multiplication of prohibitions and sanctions envisaged by legislators, the banned practice continued despite the prohibitions, demonstrating a clear variation between the metropole and Algeria. While at the beginning of the twentieth century, the reports drawn up relating to fires increased significantly in Algeria, they had already started to reduce significantly in mainland France from the middle of the nineteenth century onward. ${ }^{44}$ 
Besides this chronological gap relating to individual sanctions, the use of collective sanctions most fully reveals a colonial specificity.

\section{Collective punishment: A colonial specificity}

Collective responsibility consisted of the whole community being considering guilty of complicity where an offense had taken place. This concept was fueled by the difficulties encountered by the justice system or by the forestry services in obtaining the assistance of witnesses to establish individual responsibilities. The threat of collective responsibility sought in principle to break the wall of silence faced by the administration. ${ }^{45}$ Such measures had been applied since the period of the conquest in accordance with the 31 October 1845 royal ordinance of General Thomas Bugeaud, which authorized the imposition of collective fines or the seizure of land from insurgent tribes. Under this legislation, the criminal or insurrectional intention of forest fires had to be demonstrated or the evidence at least fabricated. In the 1874 "law relating to fires in the wooded regions of Algeria," article 1 further stipulated the prohibition of fires over the period from 1 July to 1 November, while articles 5 and 6 specified that failure to comply with this provision would allow the imposition of collective and sequestration fines on "douars and tribes": "When the fires by their simultaneity, or their nature, denote a prior agreement between the natives, they will be considered insurrectionary events, and, consequently, give rise to the application of seizures as required by the provisions in effect of royal decree of October 31, 1845." ${ }^{\prime 46}$ Officials applied collective responsibility for fires as soon as intent was established, with no culprits brought forward by friends, family, or neighbors. As a result, the number of collective fines rose to 5 in 1877, 11 in 1878, 9 in 1879, 11 in 1880, 9 in 1881, and 32 in 1882. From 1877 to 1888,90 collective fines were pronounced for fires deemed criminal. These fines applied to one or more 
douars, consisting of a higher or lower multiple of the amount of Arab taxes depending on the estimated severity of the mischief and supposed complicity. ${ }^{47}$

Although land seizures were more rarely used, in 1882, following the spectacular fires of the previous year, it was still enforced 32 times, a particularly violent and brutal means to atomize rural societies ${ }^{48}$ When the Beni Salah were found guilty in 1878 of fires spread on their lands, they were sanctioned with the possibility of buying back two-fifths of the land. They lost 4,199 hectares worth 162,395 francs and paid in addition 280,082 francs to take back a mere fraction of the seized parcels. ${ }^{49}$ Having already suffered a similar fate for the fires of 1864 and again during the 1871 insurrection, this new repressive measure resulted in the cumulative loss of 52 percent of the land that had been delimited by the senatus-consultes of 1863 . Worse still, the land seizures often directly benefited settlers. In the commune mixte of Fénaïa, seven douars bore the brunt of this sanction, their lands used to create colonization centers.

The terms of payment of the collective fines also highlight one of their functions: To provide the administration with free labor for its various works. In 1906, seven collective fines for fires were pronounced and entire populations were authorized (or forced) to provide labor in order to work off their debt. Certain communities protested, including the douars Ouled Attou, Ouled Yahia and Mouazet of the commune mixte of Telagh in the department of Oran. ${ }^{50}$ The construction of a road connecting the forest house to the main highway was considered a priority by the forest service and the working days necessary for its construction were compulsory. As usual, sanctions served colonial needs, and the legislation was never modified. Only rarely did certain administrators make exceptions to the collective nature of the sanction, and officials could veto such decisions. Thus when local authorities requested an exemption from collective responsibility for eleven individuals who participated in extinguishing a forest fire in the national forest of 
Taourira in the commune mixte of Gouraya on 25 October 1913, the administrator was told that this decision "would run counter to the principle of collective responsibility, the application of which must suppress the unwillingness to fight the fire and more particularly the tacit agreement established between the inhabitants of the community who start fires and the silence the names of the culprits. ${ }^{" 51}$ In this case, the fine equaled the annual Arab tax, meaning a doubling of the rate for local residents.

The concept of collective responsibility further entailed the establishment of lookouts to monitor possible fire outbreaks, which became widespread as the warm season approached. Adopted by certain local authorities in the forests of the department of Constantine from the early $1860 \mathrm{~s}$ onward, ${ }^{52}$ authorities systematized the practice after the fires of $1865 .{ }^{53}$ The law on forest fires adopted in 1874 established its regular functioning, article 4 making forest surveillance service compulsory for "natives" for the period 1 July to 1 November, which included lookouts and guard patrols drawn from local Algerian populations and occasionally Europeans. ${ }^{54}$ Prefects decreed this surveillance service in concert with forestry personnel or by the decision of the generals overseeing military territories. ${ }^{55}$ Failure to comply resulted in fines ranging from 20 to 500 francs and a prison sentence from six days to six months. Levied by forest guards as well as administrators and gendarmes, charges of the "abandonment of lookout posts" were frequent and consequently sanctioned. In 1905, the forest service issued 776 tickets, not including punishments regulated by the indigénat and pronounced by administrators from 1901 onward. ${ }^{56}$ The lookouts themselves operated for both fire prevention and as a form of sanction, inflicted and experienced as such by the Algerian populations. After the particularly violent fires of 1881, 2,465 lookout posts permanently employed 6,516 men for 794,952 working days. ${ }^{57}$ This proved particularly 
problematic for a population concerned at the same time with agricultural activities at a crucial time of the year.

Although inspired by the Var precedent, the law of 17 July 1874, therefore, added several significant legal provisions. There was no compulsory surveillance system in the law of 6 July 1870. Above all, articles 5 and 6 of the law, which held responsible the "tribes and douars [who] may be hit with collective fines or sequestration," radically differed from metropolitan laws. Therein lies an undeniable colonial specificity. Collective responsibility no longer existed in the Republic, and proved limited even the Old Regime.$^{58}$ For the eighteenth century, André Abbiateci examined two hundred files from the Paris Parliament judgments of arsonists, and found no collective punishment. ${ }^{59}$ However, echoing the colonial administration, he pointed out "the silence" of the accomplices vis-à-vis the accused. To circumvent this difficulty, judges privileged the recourse to methods such as torture rather than collective sanction. Yet the use of the latter nonetheless embodies the essence of colonial forest management.

This article highlights and nuances the elements of Algerian forest conflicts, which can be considered colonial specificities, drawing attention to the construction of "environmental imaginaries. ${ }^{90}$ To be sure, forest ideology had been in vogue in France for some time, clearly formulated from the beginning of the nineteenth century. The stereotypes aroused by the "natives of mainland France," in the words of Andrée Corvol concerning mountain dwellers, were merely replaced by Algerian "natives" with metropolitan speeches reused without significant modification in Algerian colonial context. ${ }^{61}$ Grazing, untimely and illegal logging, and herding movements as well as forest fires constituted themes already marked out by metropolitan foresters. They formed 
a conceptual "toolbox" that adapted perfectly to the Algerian situation. From this point of view "the environmental myths of the Maghreb," to quote Diana K. Davis, would benefit from being understood in their European genealogy rather than an orientalist one. ${ }^{62}$ Moreover, scholarly attention to the circulation of foresters instead of printed sources would help to better understand how modern forestry practices elaborate and circulate.${ }^{63}$ From this perspective, career records kept in the ANOM (Archives nationales d'outre mer) offer a good place to start.

In the same way, rural or forestry violence proved surprisingly nonspecific to the Algerian situation ${ }^{64}$ Nevertheless, state institutions responded quite differently to rural violence. There was no collective punishment in the metropole during the nineteenth century, yet this tactic was widely applied in Algeria to suppress the practice of forest fires. There officials applied it during exceptional fire years, and collective fines became more frequent. Yet neither did these practices genuinely revive a "tradition" of the Old Regime.${ }^{65}$ As such, they were indeed a colonial specificity in the nineteenth century that needed to be delimited in order to improve our understanding of the colonial situation.

Antonin Plarier is an Associate Professor at Lyon 3 University and member of the LARHRA (Rhône Alpes Historical Research Laboratory). He received his PhD in contemporary history at Université Paris I (Panthéon-Sorbonne). His thesis focused on rural banditry in Algeria during the colonial period (1871-1920s), centered on links between banditry and different types of dispossessions (land dispossessions and attacks on customary rights). After having taught at Lycée Jean Lurçat in Martigues (France), he is now teaching at Lyon 3 University. Email: antonin.plarier@univ-lyon3.fr 


\section{Notes}

1. Président de la cour d'assises de Blidah au ministre de la Justice, dossier 6618, S65, Pierrefitte, Archives Nationales, BB-24-2032.

2. Kamel Kateb, Européens, “indigènes” et juifs en Algérie (1830-1962) [Europeans, Indigens and Jews in Algeria] (Paris: Editions de 1'Institut National d'Etudes Démographiques, 2001), 85. 3. Le Temps, 1865-11-3. Le Petit Parisien, 1865-11-2. La Presse, 1865-11-2.

4. 6618. S.65, BB24-2032.

5. Antonin Plarier, "Le banditisme rural en Algérie à la période coloniale (1871—années 1920)," [Rural Banditry in Colonial Algeria (1871-1920s)] PhD diss., Panthéon Sorbonne University, Paris 2019, 106-107.

6. 6618. S.65, BB24-2032.

7. Eric J. Hobsbawm, “Social Criminality: Distinctions between Socio-Political and Other Forms of Crime," Society for the Study of Labour History. Bulletin 25 (1972), 5-6.

8. Augustin Berque, Écrits sur l'Algérie [Writings on Algeria] (1934; Aix-en-Provence: Édisud, 1986), 180.

9. Diana K. Davis, Les Mythes environnementaux de la colonisation du Maghreb [Resurrecting the granary of Rome : Environmental History and French Expansion in North Africa] (Seyssel: Champ Vallon, 2012), 45.

10. Martine Chalvet, “La vulnérabilité de la forêt provençale face aux incendies: naissance d'une notion (fin XIX ${ }^{\mathrm{e}}$ siècle)," [The vulnerability of Provençale forest in face of fires : Birth of a notion (end of nineteenth century] VertigO_la revue électronique en sciences de l'environnement 16, no. 3 (2016). 
11. Frédéric Thomas, "Protection des forêts et environnementalisme colonial: Indochine 18601945," [Forests protection and colonial environmentalism : Indochina 1860_1945] Revue d'Histoire moderne et contemporaine 56, no. 4 (2009); 104-136

12. Steven Pyne, Fire; A Brief History (Seattle: University of Washington Press, 2001), 88.

13. Ibid.

14. Léo Lamarque, De la conquête et de la colonisation de l'Algérie [The conquest and colonisation of Algeria] (Paris: Ancelin, 1841), 78.

15. R. Thibault, Des Incendies de forêts en Algérie, de leurs causes et des moyens préventifs et défensifs à leur opposer [Forest fires in Algeria, their causes and the preventive and defensive tools to struggle them] (Constantine: Vve Guende, 1866), 8.

16. René Passeron, Les grandes sociétés de colonisation dans l'Afrique du Nord [The big colonial companies in North Africa] (Algiers: Imprimerie La Typo-Litho, 1925), 38.

17. Antonin Plarier, "Population et administration forestière en Algérie (1830-1914): Des usages forestiers entre persistance et reconfiguration," Cahiers du Groupe d'histoire des forêts françaises 46 (Forthcoming 2021).

18. Martine Chalvet, Une Histoire de la forêt [An history of the forest] (Paris: Le Seuil, 2011), $120-124$.

19. Raphaëlle Branche, L'Embuscade de Palestro: Algérie 1956 [The Palestro ambush : Algeria 1956] (Paris: La Découverte, 2018), 105-120.

20. Charles-Robert Ageron, Les Algériens musulmans et la France 1871-1919 [The Algerian Muslims and France 1871-1919] (1968; repr., Paris: Bouchène, 2005), 15.

21. Ibid. 
22. Mohand Moussa in Mouloud Mammeri, ed., Poèmes kabyles anciens [Old Kabyle poems] (Algiers: Editions Mehdi, 1980), 449.

23. Ibid.

24. Conseil supérieur de gouvernement, séance du 24 février 1872 quoted in Ageron, Les Algériens musulmans et la France 1871-1919, 26.

25. André Nouschi, Enquête sur le niveau de vie des populations rurales constantinoise : De la conquête jusque 1919 [Inquiry into the living standard of rural populations in the department of Constantine : From the conquest until 1919] (1961; repr., Paris: Bouchène, 2013), 247.

26. Rapport de l'inspecteur des Eaux et Forêts de Brignole, 1861, Archives Départementales du Var, 7P9. Quoted by Chalvet, Une Histoire de la forêt, 188.

27. Officier de la légion d'honneur in 1869, AN, L2313/55. See also Chalvet, "La vulnérabilité de la forêt provençale face aux incendies."

28. This law of 17 July 1874 , however, presents significant breaks with its metropolitan equivalent. See “collective punishment: A colonial specificity”, below.

29. Exposé des motifs. Projet de loi relatif aux mesures à prendre contre les incendies dans les régions boisées de l'Algérie, s.d. vers 1874, ANOM, P61.

30. "Assemblée générale du 6 novembre" in Bulletin de la Ligue de reboisement, Algiers, s.n., $\mathrm{n}^{\circ} 1(1882): 16$.

31. “Appel aux Algériens," in Bulletin de la Ligue pour le reboisement de l'Algérie, Algiers, s.n., $\mathrm{n}^{\circ} 1(1882): 2$.

32. Ibid.

33. Diana K. Davis, Resurrecting the Granary of Rome, Environmental History and French Colonial Expansion (Athens: Ohio Press University, 2007). 
34. Guy de Maupassant, Au Soleil [The sun] (1884; repr., Paris: Gallimard, 2015), 76.

35. Antonin Plarier, “'Bandits’ recherchés aux confins algéro-tunisiens (1878-1881),” Revue d'Histoire du XIX'e siècle 56 (2018): 171-189.

36. Loi relative aux mesures à prendre en vue de prévenir les incendies dans les régions boisées de l'Algérie, 17 juillet 1874, CANA, 12E-1126.

37. The conclusions of the council are formulated as follows: " $1{ }^{\circ}$ That the cork oak forests which, in Algeria, have become the property of individuals, are freed from the forest regime. $2^{\circ}$ That the forest administration is of no quality to observe and prosecute forest crimes in these forests. $3^{\circ}$ That art. 7 of the law of July 17, 1874 prohibits only users from grazing in burnt forests, and that owners keep the option, either to graze their own cattle there, or to cede to others the right to graze."

38. Quoted in Davis, Les Mythes environnementaux de la colonisation du Maghreb, 275.

39. André Nouschi, "Notes sur la vie traditionnelle des populations forestières algériennes," [Notes on traditional life of forest Algerian populations]Annales de Géographie 68, no. 370 (1959), 525-535; Kateb, Européens, “Indigènes” et Juifs en Algérie (1830-1962), 120.

40. Procès-verbaux de la chefferie de Bouïra, 31 octobre 1910, CANA, 12E-689. 41. Ibid.

42. Gouvernement général, Exposé de la situation de l'Algérie [Presentation of the situation of Algeria] (Algiers: Imprimerie Juillet Saint-Lager, 1901), 355.

43. Rapport de l'inspecteur des Eaux et Forêts de Miliana au gouverneur général, 1904, 12E-833. 44. Andrée Corvol, L'Homme aux bois : Histoire des relations de l'homme et de la forêt XVII $X X^{e}$ [Man in the woods: History of the relationships between man and forest from the eighteenth to the twentieth century] (Paris : Fayard, 1987) 152. 
45. Jacques Bouveresse, Un parlement colonial ? Les délégations financières algériennes 18981945 [A colonial parliament? The financial Algerian delegations 1898-1945] (Mont Saint Aignan: Presses universitaires de Rouen et du Havre, 2008), 123.

46. Loi relative aux mesures à prendre en vue de prévenir les incendies dans les régions boisées de l'Algérie, 17 juillet 1874, CANA, 12E-1126; 17 juillet 1874, CANA, 12E-1126.

47. Henri Trolard, Les incendies forestiers en Algérie, Leurs causes et les moyens de remédier à ces causes [Forest fires in Algeria, their causes and tools to remediate them] (Algiers:

Imprimerie Casabianca, 1892), 70.

48. Ibid.

49. Nouschi, Enquête sur le niveau de vie des populations rurales constantinoises, 384.

50. Note au chef du $5^{\mathrm{e}}$ bureau, Alger, 3 décembre 1884, CANA, 12E-1126.

51. Procès-verbal de la séance du conseil du gouvernement, 25 janvier 1914, CANA, 12E-1360.

52. Circulaire à MM. Les généraux commandant les divisions d'Alger, d'Oran et de Constantine en date du 20 juillet 1864, ANOM, P63.

53. Circulaire à MM. Les généraux commandant les divisions d'Alger, d'Oran et de Constantine en date du 8 mai 1866, ANOM, P63.

54. Loi relative aux mesures à prendre en vue de prévenir les incendies dans les régions boisées de l'Algérie, 17 juillet 1874, CANA, 12E-1126.

55. Circulaire du préfet de Constantine à MM. Les Sous-Préfets, administrateurs et maires du département et inspecteurs des forêts, 24 mai 1886, ANOM, P61.

56. Gouvernement général, Exposé de la situation de l'Algérie (Algiers: Imprimerie Juillet SaintLager, 1906), 355.

57. Trolard, Les incendies forestiers en Algérie, 63. 
58. Chalvet, Une Histoire de la forêt, 120-123.

59. André Abbiateci, "Les incendiaires en France au XVIIIe siècle; Essai de typologie criminelle," [Incendiaries in France in eighteenth century : A essay on criminal typology] Annales: Économies, Sociétés, Civilisations 25-1 (1970): 231.

60. Burke and Davis, Environmental Imaginaries of the Middle East and North Africa, 6. The environmental imaginary expressed through declinist representations and its corollary ideology of reforestation does not necessarily feed on orientalism, as Davis suggests.

61. Paulin Trolard, La colonisation et la question forestière [The colonisation and the forest question] (Algiers : Imprimerie Casabianca), 32-35. In his work Colonization and the Forestry Question, Trolard quotes in full Humboldt, Rauch, Surell, and Élisée Reclus deeply discussing Spain and then applied their speech to Algeria.

62. Davis, Les Mythes environnementaux du Maghreb.

63. Printed sources have been privileged by an environmental history current, represented by Diana K. Davis, as well as Richard Grove or Gregory A. Barton. See Richard Grove, Green Imperialism, Colonial Expansion, Tropical Island Edens and the Origins of Environmentalism (Cambridge: Cambridge University Press, 1995); Gregory A. Barton, Empire Forestry and the Origins of Environmentalism (Cambridge: Cambridge University Press, 2002).

64. In addition to already quoted books see, for example; Frédéric Chauvaud, "Les violences rurales et l'émiettement des objets au XIXe siècle: Lectures de la ruralité," Cahiers d'histoire 42 no. 1, (1997): 49-88; Richard Hölzl, "Forests in Conflict: Rural Populations and the Advent of Modern Forestry in Pre-industrial Germany (1760-1860)," in Common Ground: Integrating the Social and Environmental in History, ed. Geneviève Massard-Guilbaud and Stephen Mosley, 198-223 (Cambridge: Cambridge University, 2011). 
65. This nuances Jean Frémigacci's conclusions, in 'L'Etat colonial français, du discours mythique aux réalités (1880-1940)," [The French colonial state, from mythic discourses to realities (1880-1940)] Matériaux pour l'histoire de notre temps 32, no. 34 (1993); 27-35. 